\title{
PENGEMBANGAN LEMBAR KERJA PESERTA DIDIK APRESIASI NOVEL BERBASIS PENDIDIKAN KARAKTER UNTUK PESERTA DIDIK KELAS XI SMK NEGERI SUMSEL PALEMBANG
}

\author{
Syilvia Novriany, Nurhayati, Mulyadi Eko Purnomo \\ Universitas Sriwijaya \\ Surel: busilvismanti2010@gmail.com
}

\begin{abstract}
Abstrak: Ini bertujuan untuk menghasilkan Lembar Kerja Siswa Berbasis Novel dengan Apresiasi Judul pada Pendidikan Karakter. Metode penelitian dan pengembangan ini memodifikasi dan mengkolaborasikan teori pengembangan Gall, Gall, dan Borg dan teori pengembangan Tessmer. Lembar Kerja Siswa yang dihasilkan oleh penelitian ini melalui tes validasi mencakup tiga aspek kelayakan: materi, bahasa, presentasi, dan grafik. Berdasarkan komentar dan saran para ahli, kesimpulannya adalah bahwa Lembar Kerja Siswa valid. Kemudian Lembar Kerja Siswa diuji satu-ke-satu dan kelompok-kelompok kecil yang menghasilkan bahwa Lembar Kerja Siswa praktis untuk digunakan. Nilai tingkat siswa meningkat dari 57,07 menjadi 82,80 (perbedaan 25,74). Dengan demikian, Lembar Kerja Siswa Berbasis Pendidikan Karakter efektif dalam meningkatkan kemampuan siswa untuk menghargai novel yang mereka baca.
\end{abstract}

Kata Kunci: Pengembangan, lembar kerja siswa, penghargaan terhadap novel, novel, pendidikan karakter

\section{DEVELOPMENT OF WORK SHEET PARTICIPANTS IN CHARACTER EDUCATION-BASED APPLICATION NOVEL FOR STUDENTS IN CLASS XI OF VOCATIONAL SCHOOL, PALEMBANG}

\begin{abstract}
This study aims to produce Student Worksheets with the title Appreciation Novel Based on Character Education. This research and development method modifies and collaborates the theories of the development of Gall, Gall, and Borg and the theory of development of Tessmer. Student Worksheets produced in this study through validation tests by three experts covering aspects of feasibility: material, language, presentation, and graphics. Based on the validation of the three experts, the conclusion is that the Student Worksheet is valid and worthy of being tested with revisions according to the comments and suggestions of experts. Then the Student Worksheets are tested one-to-one and small groups which result that the Student Worksheet is practical to use. The field trials were conducted through pretest and posttest, the average value of the students'novel appreciation increased from 57.07 to 82.80 (difference 25.74). Thus, the Student Worksheet Appreciation of Novel Based on Character Education is effective in improving the ability of students to appreciate the novels they read.
\end{abstract}

Keywords: Development, student worksheets, appreciation of novels, novels, character education

\section{PENDAHULUAN}

"Apresiasi sastra dimaknai sebagai kegiatan mengenal karya sastra hingga tumbuh pengetahuan, pengertian, kepekaan, pemahaman, penikmatan, dan penghargaan terhadap karya" (Ismawati, 2013: 174). Mengenal karya sastra dapat dilakukan melalui membaca karya sastra tersebut baik itu puisi, prosa (cerpen dan novel) atau pun naskah drama. Hal ini sejalan dengan yang disampaikan Nurhayati (2013: 3) "tidak ada satu pun konsep atau prinsip kesusastraan yang dapat menggantikan peran membaca, terutama yang penuh penghayatan".

Kegiatan mengapresiasi karya sastra untuk peserta didik kelas XI dalam Kurikulum 2013 edisi revisi merupakan salah satu kegiatan apresiasi secara 
langsung. Hal ini karena peserta didik harus membaca buku fiksi berupa kumpulan cerpen dan novel secara langsung.

Dalam silabus Kurikulum 2013 edisi revisi 2016 milik Kementrian Pendidikam dan Kebudayaan (2016)materi mengenai apresiasi novel ini terdapat dua pasang kompetensi dasar (KD) pengetahuan dan kompetensi dasar (KD) keterampilan yaitu

KD Pengetahuan3.11 menganalisis pesan dari satu buku fiksi yang dibaca, KD Pengetahuan $\quad 3.20$ menganalisis pesan dari dua buku fiksi (novel dan buku kumpulan puisi) yang dibaca, KD Keterampilan $\quad 4.11$ menyusun ulasan terhadap pesan dari satu buku fiksi yang dibaca, dan KD Keterampilan 4.20 menyusun ulasan terhadap pesan dari dua buku kumpulan puisi yang dikaitkan dengan situasi kekinian

Hasil wawancara dengan guru bahasa Indonesia kelas XI di SMK Negeri Sumsel Palembang diperoleh informasi bahwa buku yang digunakan peserta didik saat ini hanya buku teks terbitan Kementrian Pendidikan dan Kebudayaan tahun 2017. Dalam buku tersebut pembelajaran mengenai KD pengetahuan dan KD keterampilan pada tabel di atas diletakkan pada Bab paling awal yaitu Bab pengembangan literasi.

Guru bahasa Indonesia SMK Negeri Sumsel Palembang, Komariyah, S.Pd.,mengatakan dalam proses pembelajaran pendidik mengalami kesulitan untuk menghubungkan KD pengetahuan dan KD keterampilan tersebut dengan Bab Pengembangan Literasi. Hal ini disebabkan kurangnya materi pembelajaran dan langkah-langkah dalam meliterasi buku fiksi pada buku tersebut.
Panduan melakukan literasi di dalam buku ajar tersebut hanya cocok untuk buku nonfiksi saja. Peserta didik melakukan literasi buku fiksi hanya sebatas menemukan unsur-unsur intrinsik dan ekstrinsik saja. Oleh karena itulah, peserta didik membutuhkan komponen penunjang agar kegiatan literasi buku fiksi, terutama novel, yang dapat bermuara pada KD pengetahuan dan KD keterampilan yang diinginkan dalam silabus kurikulum 2013 edisi revisi.

Pengembangan bahan ajar dalam bentuk lembar kerja peserta didik saat ini menjadi suatukebutuhan. Lembar kerja peserta didik dipilih sebagai bahan ajar yang dikembangkan karena dianggap memiliki komponen lengkap dengan bentuk ringkas. Ini sejalan dengan yang disampaikan Sari, Nurhayati, \& Soetopo (2017) bahwa "lembar kerja peserta didik ialah panduan bagi peserta didik untuk melakukan rangkaian kegiatan dalam proses belajar mengajar". Oleh karena itu, LKPD diharapkan mampu menumbuhkan suasana belajar yang aktif. "Lembar kerja peserta didik dapat membantu dapat membantu peserta didik untuk berpikir, mengingat, dan mengerti materi mereka dengan mudah" (Arliyah \& Ismono, 2015). Lembar kerja peserta didik juga mempunyai manfaat bagi keberhasilan belajar peserta didik.

Peneliti juga memilih novel Pukat karya Tere Liye sebagai bahan pembelajaran apresiasi sastra. Novel ini dipilih karena dirasa sesuai dengan perkembangan karakter dan usia peserta didik. Selain itu, seperti yang telah disampaikan sebelumnya, kegiatan apresiasi novel menjadi lebih baik apabila dilakukan secara langsung.

Untuk memudahkan peserta didik dalam mengapresiasi novel Pukat karya Tere Liye maka peneliti merancang Lembar Kerja Peserta Didik Apresiasi Novel Berbasis Pendidikan Karakter. Melalui LKPD ini diharapkan peserta didik dapat menganalisis pesan dari novel Pukat karya TereLiye yang dibacanya dan 
menghubungkan pesan tersebut dengan nilai pendidikan karakter versi kementrian pendidikan nasional. Pendidikan berbasis karakter ini didasarkan pada Peraturan Presiden Republik Indonesia Nomor 87 (2017) tentang "Penguatan Pendidikan Karakter dengan 18 nilai karakter religius, jujur, toleransi, disiplin, kerjakeras, kreatif, mandiri, demokratis, rasa ingin tahu, semangat kebangsaan atau nasionalisme, cinta tanah air, menghargai prestasi, komunikatif, cinta damai, gemar membaca, peduli lingkungan, peduli sosial, dan tanggung jawab".

Penelitian-penelitian yang relevan sudah pernah dilakukan oleh para peneliti terdahulu, di antaranya penelitian yang dilakukan Rahmasari, Purnomo, \& Nurhayati (2016) berjudul "Pengembangan Buku Ajar Apresiasi Puisi Bermuatan Nilai Iman, Islam, dan Ihsan pada Peserta Didik MTs Muqimus Sunnah Palembang”. Selanjutnya, penelitian dengan judul "Pengembangan Lembar Kerja PesertaDidik (LKPD) Elektronik Menulis Teks Cerita Pendek Berbasis Budaya Lokal" oleh Sari, Nurhayati, \& Soetopo (2017). Penelitian Ketiga, dilakukan oleh Hardayanti, Nurhayati, \& Suhendi (2018) dengan judul "Pengembangan Lembar Kerja Peserta Didik (LKPD) Memahami Teks Cerita Rakyat Berbasis Kearifan Lokal di Sumatera Selatan”.

Penelitian ini memiliki kesamaan dengan penelitian sebelumnya yaitu jenis penelitiannya merupakan penelitian dan pengembangan yang menghasilkan bahan ajar. Sedangkan perbedaannya terletak pada produk yang dihasilkan, teori yang digunakan dan objek yang diteliti. Penelitian ini nantinya menghasilkan bahan ajar berbentuk LKPD berbasis pendidikan berkarakter untuk pembelajaran apresiasi novel bagi siswa kelas XI SMK Negeri SUMSEL Palembang.

Berdasarkan latar belakang di atas, tujuan penelitian ini yaitu, 1) Mendeskripsikan kebutuhan lembar kerja peserta didik apresiasi novel berbasis pendidikan karakter bagi guru dan peserta didik kelas XI SMK Negeri SUMSEL Palembang, 2) Menghasilkan prototype lembar kerja peserta didik apresiasi novel berbasis pendidikan karakter. 3) Mendeskripsikan validitas lembar kerja peserta didik apresiasi novel berbasis pendidikan karakter berdasarkan penilaian dari tim ahli, 4) Mendeskripsikan kepraktisan lembar kerja peserta didik apresiasi novel berbasis pendidikan karakter berdasarkan uji coba one-to-one evaluation dan small grup evaluation, 5) Mendeskripsikan keefektifan lembar kerja peserta didik apresiasi novel berbasis pendidikan karakter berdasarkan uji cobafield test.

MenurutTrianto (2010: 111) Lembar kerja peserta didik merupakan panduan bagi siswa untuk melakukan kegiatan yang mendasar untuk memaksimalkan pemahaman sesuai indikator pencapaian hasil belajar. Selain memuat panduan untuk latihan yang mengembangkan aspek kognitif, lembar kegiatan ini biasanya juga memuat panduan untukmengembangkan aspek pembelajaran dalam bentuk eksperimen atau demonstrasi.

Ada enam unsur struktur LKPD menurut Prastowo (2012: 208) utama yaitu; judul, petunjuk belajar, kompetensi dasar atau materi pokok, informasi pendukung, tugas atau langkah kerja, dan penilaian. Berdasarkan pendapat tersebut unsur-unsur di dalam lembar kerja peserta didik yang akan dikembangkan dalam penelitian ini, yaitu judul, petunjuk penggunaan, Kompetensi Dasar keterampilan dan pengetahuan, tujuan pembelajaran, materi pembelajaran, latihan, rubrik penilaian, dan daftar pustaka.

Di dalam LKPD apresiasi novel ini juga akan dilampirkan novel Pukat karya Tere Liye. Novel ini dipilih karena mengandung nilai-nilai yang sesuai dengan pendidikan karakter. Selain itu novel ini dirasa sesuai dengan perkembangan karakter dan usia peseta didik. Novel tersebut akan diapresiasi baik secara 
anatomis (bagian-bagian) maupun komprehensif (menyeluruh). Sehingga apabila peserta didik telah menyelesaikan berbagai latihan dan evaluasi di dalam LKPD ini maka peserta didik dapat dipastikan telah membaca novel Pukat secara keseluruhan.

Dalam bahasa Indonesia kata apresiasi berasal dari kata appreciation yang mempunyai arti memberikan penghargaan. Menurut Suroto (1989:157)“Secara grama tikal kata apresiasi atau penghargaan dapat diberi makna sebagai proses atau hal memberi harga atau menghargai". Sedangkan pengertian novel dalam Kamus Lengkap Bahasa Indonesia (2002: 359) "adalah tulisan berupa karangan prosa yang panjang dan menceritakan sebuah kisah". Dari uraian di atas dapat ditarik kesimpulan bahwa apresiasi novel adalah kegiatan memahami dan menikmati karangan prosa fiksi hingga tumbuh pengetahuan, pemahaman dan penghargaan terhadap karya tersebut.

Untuk sampai pada proses memberikan penghargaan ada beberapa proses/tingkatan dalam apresiasi. Tingkatan tersebut menurut Ahmadi (1990: 52) yaitu “a) tingkat menggemari, b) tingkat menikmati, c) tingkat merespons atau mereaksi, dan d) tingkat produktif.

Apresiasi novel memiliki tiga aspek utama yaitu kognitif, emotif dan evaluatif. Ini sejalan dengan pendapat Ismawati (2013) bahwa "apresiasi melibatkan tiga unsur inti yaitu, Pertama aspek kognitif berkaitan dengan pengetahuan peserta didik terhadap berbagai teori yang mendukung apresiasi novel. Kedua aspek emotif berkaitan dengan keterlibatan unsur emosi pembaca, Ketigaaspekevaluatif berkaitan dengan kegiatan memberikan penilaian terhada pindah - tidak indah, baik - buruk, karya sastra yang dibaca.

Pendidikan karakter dapat dimaknai sebagai pendidikan nilai, pendidikan budi pekerti, pendidikan moral, pendidikan watak, yang bertujuan mengembangkan kemampuan peserta didik untuk memberikan keputusan baik-buruk, memelihara apa yang baik, mewujudkan, dan menebar kebaikan itu dalam kehidupan sehari-hari dengan sepenuh hati (Arifin \& Barnawi, 2012). Ada 18 nilai karakter yang harus ditanamkan dalam diri peserta didik berdasarkan buku Panduan Pelaksanaan Pendidikan Karakter terbitan Kementrian Pendidikan Nasional Badan Penelitian dan Pengembangan Pusat Kurikulum dan Perbukuan (2011: 8) yaitu, religius, jujur, toleransi, disiplin, kerjakeras, kreatif, mandiri, demokratis, rasa ingin tahu, semangat kebangsaan atau nasionalisme, cinta tanah air, menghargai prestasi, komunikatif, cintadamai, gemarmembaca, peduli lingkungan, peduli sosial, dan tanggung jawab.

\section{METODE PENELITIAN}

Dalam penelitian ini metode yang digunakan adalah metode penelitian dan pengembangan (Research and Development). Penelitian ini mengadaptasi dan memodifikasi model pengembangan Gall, Gall, \& Borg (2003) dan model pengembangan Tessmer (1998). Prosedur penelitian pengembangan yang dilakukan dalam penelitian ini mencakup beberapa langkah pengembangan.

Langkah-langkah penelitian pengembangan bahan ajar dengan model pengembangan Gall, Gall, \& Borg (2003) dan Tessmer (1998) dapat diuraikan sebagai berikut, (1) Penelitian dan Pengumpulan Informasi, pada tahap ini melakukan analisis terhadap kuesioner untuk mengetahui kebutuhan guru dan peserta didik terhadap bahan ajar yang sesuai dengan tuntutan Kurikulum 2013 edisi revisi 2016; (2) Perencanaan, pada tahapini, melakukan perancangan pada prototipe yang dibahas bersama para ahli untuk menghasilkan prototype awal dan pedoman pada pengembangan yang kemudian akan diuji kelayakan; (3) Pengembangan ProdukAwal, pada tahap ini peneliti mengembangkan bahan ajar ke dalam bentuk lembar kerja peserta didik (LKPD); (4) Evaluasi Mandiri, pada tahap 
ini peneliti dan pembimbing peneliti melakukan evaluasi prototipe yang telah didesain. Peneliti kemudian melakukan revisi prototipe LKPD setelah mendapat masukan dari dosen pembimbing; (5) Validasi Ahli, validasi ahli adalah evaluasi yang dilakukan oleh ahli dalam mengkaji prototype pengembangan LKPD apresiasi novel berbasis pendidikan karakter untuk kelas XI SMK Negeri SUMSEL Palembang. Dalam penelitian ini validasi yang dilakukan mencakup validasi isi/materi, validasi bahasa, validasi penyajian; (6) One-to-One Evaluation (evaluasi orang per orang), Ditahap ini, prototype produk hasil pengembangan diberikan kepada peserta didik untuk dipelajari. Informasi yang diperoleh dalam one-to-oneevaluation ini mencakup tingkat kesulitan dan kejelasan materi, latihan, evaluasi, penggunaan bahasa, kemenarikan, dan kebermanfaatan bahan ajar. Informasi tersebut digunakan untuk merevisi bahan ajar; (7) Small Grup Evaluation (Evaluasi Kelompok Kecil), pada tahap ini prototype produk yang telah direvisi berdasarkan hasil validasi ahli dan one-to-one evaluation diujicobakan kepada kelompok kecil yang berjumlah 8-15 peserta didik; (8) Field Test (Uji Coba Lapangan), tahap ini dilakukan untuk mengukur keefektifan produk. Jumlah peserta didik yang dilibatkan pada tahap ini adalah 30 peserta didik.

Subjek penelitian terdiri atas satu orang guru bahasa Indonesia dan satukelas XI yang berjumlah 30 orang peserta didik di SMK Negeri SUMSEL Palembang. Kelas yang digunakan adalah kelas XI jurusan Tehnik Instalasi Tenaga Listrik (TITL) 2. Jurusan ini mempelajari mengenai instalasi listrik listrik rumah dan penerangan jalan raya.

Teknik pengumpulan data yang digunakan dalam penelitian ini adalah teknik angket/kuesioner, wawancara, lembar penilian, dan tes. Jenis data yang diperoleh dalam penelitian ini adalah data kualitatif dan data kuantitatif. Data kualitatif diperoleh dari wawancara kepada guru mata pelajaran bahasa Indonesia, tanggapan para ahli (expert review) saat validasi produk hasil pengembangan bahan ajar, serta tanggapan peserta didik saat one-to-one evaluation dan small grup evaluation. Data kuantitatif diperoleh dari skor nilai yang terdapat pada setiap kuesioner yang diberikan kepada peserta didik dan hasil pretest dan posttest saatfield test.

Langkah-langkah analisis data dalam penelitian ini sebagai berikut; (1) semua data yang berhasil dikumpulkan oleh peneliti diklasifikasikan sesuai dengan jenis data kuantitatif dan kualitatif, (2) data direduplikasi dan disajikan dengan menggunakan table, bagan, atau grafik sesuai dengan kebutuhan penelitian, (3) hasil validasi ahli terhadap LKPD direvisi, (4) hasil revisi produk diujicobakan kepada peserta didik secara one-to-one evaluation, small grup evaluation, dan field test.

\section{HASIL DAN PEMBAHASAN}

Lembar Kerja Peserta Didik (LKPD) Apresiasi Novel Berbasis Pendidikan Karakterinimerupakan LKPD yang digunakan sebagai pelengkap dan penunjang buku teks dalam pembelajaran mengapresiasi novel. LKPD ini dapat digunakan guru dan peserta didik pada kegiatan belajar mengajar di kelas. Hal ini sesuai dengan fungsi LKPD menurut Sari, Nurhayati, dan Soetopo (2004) yaitu sebagai panduan bagi peserta didik untuk melalakukan rangkaian kegiatan dalam proses belajar mengajar. LKPD diharapkan dapat menciptakan suasana belajar aktif. Suasana tersebut adalah suasana yang membuat peserta didik dapat melakukan pengalaman, interaksi, komunikasi, dan refleksi.

LKPD Apresiasi Novel Berbasis Pendidikan Karakter ini dikembangkan berdasarkan hasil analisis kebutuhan peserta didik dan guru. Ada beberapa hasil analisis kebutuhan yang diakomodasikan ke dalam LKPD dan ada beberapa yang tidak diakamodasikan ke dalam LKPD. 
Analisis kebutuhan yang diakomodasikan ke dalam LKPD, yaitu 1) pengembangan bahan ajar berupa LKPD dalam mengapresiasi novel, 2) novel yang digunakan berbasis pendidikan karakter, 3) novel yang digunakan adalah novel Pukat karya Tere Liye, 4) LKPD yang dikembangkan memuat materi teori apresiasi novel, menganalisis dan mengomentari unsur-unsur intrinsik, dan langkah-langkah membuat teks ulasan novel, 5) rancangan LKPD memuat judul, mata pelajaran, $\mathrm{KI}, \mathrm{KD}$, tujuan pembelajaran, informasi pendukung, latihan, petunjuk kerja, dan penilaian. 7) format LKPD berukuran 12-14 pts, 8) Desain LKPD menarik, sederhana, dan ilustratif, 8) kertas LKPD kuat dan berkualitas, 9) konsep penyajian LKPD disajikan secara runtun, 10) Penyajian LKPD terdiri atas; kata pengantar, daftar isi, peta kompetensi, petunjuk penggunaan LKPD, uraian tentang apa yang akan dicapai peserta didik, uraian materi, latihansoal, rubrik penilaian, daftar pustaka, dan biodata penulis, 11) Bentuk soal yang digunakan dalam LKPD adalah bentuk essai. Sebaliknya ada dua analisis kebutuhan yang tidak diakomodasikan kedalam LKPD yaitu, 1) pilihan pengunaan gambar dan ikon dalam LKPD. 2) bentuk soal pilihan ganda. Hal ini disebabkan dua hal tersebut tidak sesuai dengan konsep LKPD yang akan dikembangkan.

Kehadiran LKPD ini menjadi bahan ajar yang valid, praktis, dan efektif dalam mempelajari materi teks ulasan novel.Sesuai dengan pendapat Nieveen (dalam Akker dkk., 1999:126) mengenai 3 (tiga) kriteria untuk mengukur kualitas produk pembelajaran, yaitu validitas, kepraktisan, dan keefektifan.

LKPD ini juga dirancang secara sistematis. Isi yang terdapat pada LKPD ini terdiridari: (1) sampuldepan (2) kata pengantar, (3) daftar isi, (4) Kompetensi Dasar (KD) dan Kompetensi Inti (KI), (5) penjelasan mengenai isi LKPD, (6) kompetensi dasar dan tujuan pembelajaran.
(5) materi, (6) latihan, (7) rubrik penilaian, (9) daftar pustaka, dan (10) biodata penulis.

Rancangan bahan ajar dibuat setelah melakukan analisis kebutuhan. Secara umum LKPD Apresiasi Novel Berbasis Pendidikan Karakter yang dikembangkan ini terdiri dari tiga bagian yaitu bagian pendahuluan, isi, dan penutup. Bagian pendahuluan, yang berisi (a) sampul depan/ cover, (b) kata pengantar, (c) daftar isi, (d) kompetensi inti (KI) dan kompetensi dasar (KD), (e) petunjuk LKPD, (f) uraian mengenai apresiasi novel. Bagian isi, terdiri atas (a) pembelajaran I, (b) pembelajaran II, (c) pembelajaran III, dan (d) pembelajaran IV, yang masing-masingberisi: tujuan pembelajaran, materi, tugas dan langkahkegiatan, dan rubrikpenilaian. Bagian penutup, terdiri atas (a) daftar pustaka, dan (b) biodata penulis.

Jenis latihan di dalam LKPD ini adalah SoalEssai. Setelah mempelajari materi pembelajaran peserta didik diharuskan membaca novel secara terbimbing (bab yang harus dibaca berdasarkan tugas dan langkah kegiatan yang terdapat di setiap bab) kemudian peserta didik menjawab soal-soal essai yang berhubungan dengan materi dan novel yang dibacanya. Kemudian pada evaluasi akhir peserta didik akan berlatih membuat teks ulasan novel Pukat karya Tere Liye dengan memperhatikan struktur yang terdapat di dalam teks ulasan.

Setelah membuat rancangan produk melalui hasil analisis kebutuhan (guru dan peserta didik), dilakuka nself evaluation oleh peneliti dan dosen pembimbing. Hasil dari self evaluation adalah memperbaiki kesalahan teknis penulisan (tanda baca, ejaan, sapaan), materi dan latihan yang diberikan harus sesuai dengan tujuan pembelajaran, kesesuaian pemilihan warna pada LKPD dan pemilihan novel harus disesuaikan dengan peserta didik. Peneliti kemudian merevisi rancangan produk hasil self evaluation serta mengembangkan desain berupa prototipe. 
Selanjutnya, prototype produk divalidasi oleh tim ahli. Validasi dalam penelitian ini mencakup empat aspek, yaitu aspek kelayakan materi, bahasa, penyajian dan kegrafikaan. Setiap ahli memberikan penilaian, komentar, dan saran yang kemudian direvisi oleh peneliti.

Validasi terhadap LKPD Apresiasi Novel Berbasis Pendidikan Karakter ini dilakukan pada tanggal 2-11 Februari 2019. Aspek yang divalidasi terdiri dari empat aspek yaitu aspek kelayakan isi/materi, kebahasaan, penyajian, dan kegrafikaan.

Validasi pertama dilakukan oleh ahli kelayakan isi/materi. Validator materi adalah dosen Program Studi Magister Pendidikan Bahasa FKIP Universitas Sriwijaya denganpendidikan S3 dalam ilmu sastra. Aspek penilaian terdiri dari 14 komponen dengan skala $1-5$. Secara keseluruhan, dari skor maksimal 70 , komponen kelayakan isi/materi memperoleh skor 59.

Saran yang diberikan validator adalah tambahkan materi watak, fokuskan tugas dan langkah kegiatan pada tujuan pembelajaran yang telah dibuat, berikan contoh singkat setiap tahapan alur dan jenis perwatakan, kalimat dalam tujuan pembelajaran tidak konsisten, dan terjadi tumpang tindih tujuan pembelajaran bab II dan bab III.

Validasi kedua dilakukan oleh ahli bahasa, Validator bahasa adalah dosen Program Studi Pendidikan Bahasa dan Sastra Indonesia Fakultas Keguruan dan Ilmu Pendidikan (FKIP) Universitas Tridinanti Palembang. Aspek penilaian terdiri dari 14 komponen dengan skala $1-$ 5. Secara keseluruhan, dari skor maksimal 70, komponen kelayakan bahasa memperoleh skor 65 .

Saran yang diberikan validator adalah perhatikan penggunaan kalimat efektif, kurang konsisten dalam menggunakan kata, jenis huruf, ukuran huruf, serta spasi dalam setiap soal, penomoran dan sub judul ada yang terlewat, terlalu banyak kata "-nya", dan gunakan tanda baca untuk batas kalimat, sehingga kalimat mudah dipahami.

Validasi ketiga adalah validasi penyajian dan kegrafikaan. Validator penyajian dan kegrafikaan dosen Program Studi Magister Bahasa FakultasKeguruan dan Ilmu Pendidikan Universitas Sriwijaya. Terdapat 10 komponen aspek penilaian dalam validasi penyajian. Skala penilaian 1-5. Dari skor maksimal 50, kelayakan penyajian memperoleh skor 42 . Sedangkan aspek validasi kegrafikaan terdiri dari 6 komponen dengan skala $1-$ 5. Validasi penyajian memperoleh skor 25 dari skor maksimal 30.

Saran yang diberikan validator untuk penyajian LKPD adalah sebaiknya diformat dalambentuk tabel dan tujuan disesuaikan dengan indikator. Sementara itu,untuk kegrafikaannya tidak ada masukan yang diberikan oleh validator.

Kemudian peneliti melakukan revisi berdasarkan saran yang diberikan oleh para ahli. Tahap berikutnya, dilakukan uji coba one-to-one pada LKPD Apresiasi Novel Berbasis Pendidikan Karakter yang telah direvisi. Hasil uji coba one-to-one rata-rata penilaian 53,3 dari skor maksimal 60 . Dengan kata lain LKPD Apresiasi Novel Berbasis Pendidikan Karakter praktis digunakan.

Selanjutnya dilakukan uji coba small group pada Lembar Kerja Peserta Didik ini. Hasil uji coba small group LKPD ini praktis digunakan karena mendapatkan rata-rata penilaian 50,33 dari skor maksimal 60.Walaupun terkategori praktis, akan tetapi LKPD ini masih ada kekurangan yang disampaikan oleh beberapa peserta didik melalui kolom komentar pada lembar penilaian uji coba one-to-one dan small group yaitu, 1) ada soal latihan yang kurang sesuai dengan materi pembelajaran sehingga peserta didik menjadi bingung ketika mengerjakannya, 2) sebaiknya di dalam LKPD ini ditambahkan gambar dan warna yang menarik, dan 3) masih adanya kesalahan pengetikan di dalam LKPD ini. 
Selanjutnya dilakukan uji coba lapangan (field test). Masing-masing peserta didik diberikan soal pretes dan posttes. Soalnya berupa unjuk kerja menulis teks ulasan novel yang dibaca. Hasil field test menunjukkan adanya peningkatan kemampuan peserta didik dalam menulis teks ulasan novel dari ratarata 57,07 menjadi 82,80 (selisih 25,74).

Hal ini disebabkan LKPD Apresiasi Novel Berbasis Pendidikan Karakter dilengkapi dengan petunjuk membaca novel Pukat karya Tere Liye secara terbimbing. Prosedur membaca terbimbing membantu peserta didik meningkatkan kemampuan dalam mengelola informasi. Ini sejalan dengan yang disampaikan Manzo (dalam Tierney, Readance, \& Dishner, 1990:242) bahwa "Prosedur membaca terbimbing dirancang untuk membantu peserta didik mengungkapkan kembali isi teks tanpa melihat bacaan dan meningkatkan aspek sikap dan keterampilan membaca pemahaman".

Selanjutnya, Manzo (dalam Tierney, 1990: 243) mengemukakan bahwa ada enam langkah dasar yang harus dilakukan pada saat prosedur membaca terbimbing yaitu 1) menyiapkan peserta didik untuk penugasan membaca, 2) Peserta didik membaca dan mengingat kembali informasi, 3) peserta didik membaca kembali artikel untuk mendapatkan fakta tambahan dan koreksi, 4) mengelola materi yang telah diingat, 5) memberikan pertanyaan yang menekankan pemikiran kepada peserta didik, dan 6) menguji pengetahuan peserta didik tentang informasi yang telah diberikan.

Berdasarkan langkah-langkah di atas, penulis mengimplementasikan langkah kegiatan pada LKPD sebagai berikut: 1) Guru membagikan LKPD Apresiasi Novel Berbasis Pendiidkan Karakter kepada peserta didik, 2) Peserta didik dibagi menjadi beberapa kelompok, 3) Peserta didik membaca novel berdasarkan petunjuk pada LKPD. Ketika peserta didik telah menyelesaikan bacaan, guru meminta pesertadidik untuk mengisi
LKPD di kelas, 4) Salah satu anggota kelompok membacakan informasi yang ditemukannya, 5) Guru memberikan arahan informasi yang tepat.

Selain prosedur membaca terbimbing, peningkatan juga terjadi karena peserta didik telah mengerjakan soal-soal latihan yang terdapat di dalam LKPD Apresiasi Novel Berbasis Pendidikan Karakter. Soal-soal latihan tersebut disusun secara sistematis dari yang mudah ke yang sukar. Dari kegiatan menganalisis unsur-intrinsik, mengomentari unsur-unsur intrinsik hingga menyusun teks ulasan novel diakhir latihan. Edward L. Thorndike (dalam Supardi, 2012) menyatakan bahwa salah satu dari 8 prinsip pembelajaran adalah urutan yang tepat. Urutan belajar paling efektif dimulai dari apa yang sudah dikuasai kemudian melangkah ke hal yang baru. Selain itu dapat juga dari hal yang sederhana menuju hal yang kompleks.

Keefektifan LKPD Apresiasi Novel Berbasis Pendidikan Karakter dipengaruhi oleh beberapa hal. LKPD Apresiasi Novel Berbasis Pendidikan Karakter memiliki kelebihan yaitu. (1) LKPD memiliki latihan-latihan yang sesuai dengan tujuan pembelajaran. (2) Dalam LKPD ini terdapat contoh-contoh di setiap sub babnya sehingga memudahkan peserta didik dalam menyusun teks ulasan. (3) LKPD Apresiasi Novel Berbasis Pendidikan Karakter memiliki rubrik penilaian yang dapat membantu guru dan pesertadidik dalam proses penilaian. Rubrik penilaian tidak hanya pada ranah kognitif akan tetapi pada ranah psikomotor dan afektif sehingga membantu dalam proses penilaian karakter peserta didik.

Selain kelebihan, LKPD ini juga memiliki kekurangan yaitu(1) LKPD ini memerlukan biaya tambahan untuk mencetak dan memperbanyak. (2) Apabila guru mengganti novel yang digunakan dengan novel lain maka ada beberapa soalsoal latihan yang tidak dapat digunakan karena isinya terkait dengan novel Pukat karya Tere Liye. 


\section{PENUTUP}

Berdasarkan hasil penelitian yang telah dilakukan, dapat disimpulkan hal-hal berikut. Hasil identifikasi kebutuhan peserta didik dan guru SMK Negeri Sumsel relatif sama terhadap kebutuhan bahan ajar berbentuk LKPD apresiasi novel berbasis pendidikan karakter. Kebutuhan tersebut berkaitan dengan materi pembelajaran, contoh sebelum latihan dilakukan, tugas-tugas, dan penilaian.

Dalam penelitian ini LKPD yang dihasilkan sesuai dengan kebutuhan peserta didik dan guru yang terdiri atas 1) bagian pendahuluan, yang berisi (a) sampul depan/ cover, (b) kata pengantar, (c) daftar isi, (d) kompetensi inti (KI) dan kompetensi dasar (KD), (e) petunjuk LKPD, (f) uraian mengenai apresiasi novel. 2) bagian isi, terdiriataspembelajaran I, pembelajaran II, pembelajaran III, dan pembelajaran IV, yang berisi: (a) tujuan pembelajaran, (b) materi, (c) tugas dan langkah kegiatan, (d) rubrik penilaian. 3) bagian penutup, terdiri atas (a) daftar pustaka, dan (b) biodata penulis.

LKPD apresiasi novel dikategorikan baik atau valid. Hal ini dibuktikan dari skor kelayakan substansi materi, bahasa,

\section{REFERENSI}

Ahmadi, M. (1990). Strategi BelajarMengajar; Keterampilan Berbahasa \& Apresiasi Sastra. Malang: Yayasan Asih Asah Asuh Malang (YA3 Malang).

Akker, J. van den. (1999). Principles and Method pf Development Research. London. Dalam van den Akker, J., Branch, R.M., Gustafson, K., Nieveen, N., \&Plomp, T."Design Approaches and Tools in Educational and Training.Dordrecht: Kluwer Academic Publisher.

Arifin, M. dan Barnawi. (2012). Strategi Dan Kebijakan Pembelajaran penyajian, dan kegrafikaan yang diperolehdari para ahli.

LKPD apresiasi novel sebagai hasil penelitian ini dikategorikan sangat praktis berdasarkan uji kepraktisan melalui one-toone evaluation dan small group.

Melalui uji coba lapangan (field test) LKPD yang dihasilkan dikategorikan efektif. Keefektifan LKPD dapat dilihat dari adanya perbandingan nilai rata-rata pretest dan posttest. Rata-rata nilai peserta didik mengalami peningkatan dari 57,07 pada pretest menjadi 82,80 pada posttest (selisih 25,74)

Sehubungan dengan beberapa kesimpulan yang telah dikemukakan tersebut. Berikut beberapa saran yang dapat dijadikan bahan pertimbang. Untuk dapat meningkatkan keterampilan mengapresiasi novel yang dibaca, LKPD Apresiasi Novel Berbasis Pendidikan Karakter dapat digunakan oleh peserta didik dan guru.

Peneliti selanjutnya, disarankan agar dapat mengembangkan LKPD terkait materi apresiasi novel sehingga peserta didik tidak hanya membaca novel saja akan tetapi dapat memberi penilaian terhadap novel yang dibacanya dengan cara menulis teks ulasan novel tersebut.

Pendidikan Karakter. Yogyakarta: Ar-Ruzz Media

Arliyah, A., N., \& Ismono. (2015). Development of Student Worksheet with Mind Mapping Oriented Using Mind Map Application for Atomic Structure and The Periodic System of Elements Topic. UNESA Journal of Chemical Education, 4(3).

Departemen Pendidikan Nasional. 2002. Kamusbesarbahasa Indonesia. Jakarta:Balai Pustaka.

Gall, M., D., Gall, J., P., \& Borg, W., R. (2003). Educational Research: An introduction. Boston, MA: Pearson Education, Inc. 
Hardayanti, R., Nurhayati, \& Suhendi, D. (2018). Pengembangan Lembar Kerja Peserta Didik (LKPD) Memahami Teks Cerita Rakyat Berbasis Kearifan Lokal di Sumatera Selatan. Tesis. Palembang: FKIP Unsri.

Ismawati, E. (2013). Pengajaran Sastra. Yogyakarta: Ombak.

Kementrian Pendidikan dan Kebudayaan. (2016). Silabus Mata Pelajaran Sekolah Menengah Atas/Madrasah Aliyah Kejuruan (SMA/MA/SMK/MAK) Mata Pelajaran Bahasa Indonesia.

Kementrian Pendidikan Nasional. (2011). Panduan Pelaksanaan Pendidikan Karakter. Diakses dari file:///C:/Users/User/Downloads/PA NDUAN\%20PELAKSANAAN\%20 PENDIDIKAN_KARAKTER.pdf

Nurhayati. (2013). Apresiasi Prosa Fiksi Indonesia. Surakarta: Cakrawala Media

Peraturan Presiden Republik Indonesia Nomor 87 tahun 2017. (2017). Peraturan Presiden Republik Indonesia Nomor 87 tahun 2017 tentang penguatan pendidikan karakter.

Prastowo, A. (2012). Panduan Kreatif Membuat Bahan Ajar Inovatif. Yogyakarta: Diva Press.

Rahmasari, Purnomo, M., E.,\& Nurhayati. (2016). Pengembangan Buku Ajar Apresiasi Puisibermuatannilaiiman,
Islam, dan Ihsan pada Pesertadidik MTS Muqimus Sunnah Palembang. Tesis. Tidak dipublikasikan. Palembang: FKIP Unsri.

Sari, F. N., Nurhayati, N., \& Soetopo, S. (2017). Pengembangan Lembar Kerja Peserta Didik (LKPD) Elektronik Teks Cerita Pendek Berbasis Budaya Lokal. Seminar Nasional Pendidikan Bahasa Indonesia, 1(1). Diakses dari http://www.conference.unsri.ac.id/in dex.php/SNBI/article/view/505

Supardi, E. (2012, September 29). 8 Prinsip Belajar. Diakses dariGuru Indonesia website: http://guruina.blogspot.com/2012/09/8-prinsipbelajar.html

Suroto. (1989). Teori dan Bimbingan Apresiasi Sastra Indonesia Untuk SMU. Jakarta: Erlangga.

Tessmer. (1998). Planning and Conducting Formative Evaluation: Improving The Quality of Education And Training. London: Kogan Page.

Tierney, RJ, Readance, J.E, \& Dishner, E.K. (1990). Reading Strategies and Practices. Boston, MA: Allyn and Bacon.

Trianto. (2010). Mendesain Model Pembelajaran Inovatif-Progresif: Konsep, Landasan, dan Implementasinya pada Kurikulum Tingkat Satuan Pendidikan (KTSP). Jakarta: Kencana Prenada Media Group. 